\title{
COOPERATIVE INTEGRATED READING COMPOSITION (CIRC): STRATEGI UNTUK MENINGKATKAN KEMAMPUAN PEMAHAMAN BACAAN BAGI SISWA KELAS V SEKOLAH DASAR
}

\author{
Doddy Hendro Wibowo \\ Fakultas Psikologi Universitas Kristen Satya Wacana Salatiga \\ Email: doddy.hendro@gmail.com
}

\begin{abstract}
This study aims to determine the effectiveness of teaching methods Cooperative Integrated Reading Composition (CIRC) to improve reading comprehension ability for students of classes V Elementary School. The hypothesis of this study was difference in change ability reading of comprehension stage for fifth grade students Elementary School with the teaching methods Cooperative Integrated Reading and Composition (CIRC) and that does not use teaching methods Cooperative Integrated Reading and Composition (CIRC). The subjects were fifth grade students amount 29 students, 14 of control group students and 15 of experimental group student. Data analysis technique using Mann Whitney U test. the result obtained the value of $U=98.5$, greater than $\alpha=0.05$ it can be concluded that Ho is accepted. It was concluded that there was no difference in change ability reading of comprehension stage for fifth grade students Elementary School with the teaching methods Cooperative Integrated Reading and Composition (CIRC) and that does not use teaching methods Cooperative Integrated Reading and Composition (CIRC).
\end{abstract}

Keywords: Ability of Reading Comprehension, Learning Method Cooperative Integrated Reading and Composition (CIRC), Student Class V

\section{INTISARI}

Penelitian ini bertujuan untuk mengetahui efektifitas metode pembelajaran Cooperative Integrated Reading Composition (CIRC) dalam meningkatkan kemampuan pemahaman bacaan bagi siswa kelas $\mathrm{V}$ Sekolah Dasar. Hipotesis penelitian ini adalah adanya perbedaan perubahan kemampuan membaca tahap pemahaman bagi siswa kelas V Sekolah Dasar dengan yang menggunakan metode pembelajaran Cooperative Integrated Reading and Composition (CIRC) dan yang tidak menggunakan metode pembelajaran Cooperative Integrated Reading and Composition (CIRC). Subjek penelitian adalah siswa kelas V berjumlah 29 siswa, 14 siswa kelompok kontrol dan 15 siswa kelompok eksperimen. Teknik analisa data menggunakan Uji U Mann Whitney. Hasil perhitungan diperoleh nilai U=98,5, lebih besar dari $\alpha=0,05$, maka dapat disimpulkan bahwa Ho diterima. Disimpulkan bahwa tidak ada perbedaan perubahan kemampuan membaca tahap pemahaman bagi siswa kelas V Sekolah Dasar dengan yang menggunakan metode pembelajaran Cooperative Integrated Reading and Composition (CIRC) dan yang tidak menggunakan metode pembelajaran Cooperative Integrated Reading and Composition (CIRC).

Kata Kunci: Kemampuan Pemahaman Bacaan, Metode Pembelajaran Cooperative Integrated Reading and Composition (CIRC), Siswa Kelas V.

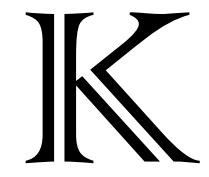

emampuan membaca sangat dibutuhkan siswa berkaitan dengan proses belajar di sekolah. Apabila anak tidak mampu untuk membaca, maka anak dapat dikatakan gagal secara akademis. Kemampuan membaca merupakan dasar untuk menguasai berbagai bidang studi. Jika anak pada usia sekolah tidak segera memiliki kemampuan membaca, maka ia akan mengalami banyak 
kesulitan dalam mempelajari berbagai bidang studi pada kelas-kelas berikutnya di mana bahan pelajaran akan semakin beragam. Oleh karena itu, Lerner menjelaskan anak harus belajar membaca agar ia dapat membaca untuk belajar (Abdurrahman, 1999).

Pentingnya pembelajaran pemahaman bacaan menurut Departemen Pendidikan dan Kebudayaan (Somadayo, 2011) adalah untuk memahami isi, menyerap pikiran, dan perasaan orang lain melalui tulisan. Mercer (Abdurrahman, 1999) menambahkan bahwa membaca juga dapat memungkinkan seseorang meningkatkan keterampilan kerja dan penguasaan berbagai bidang akademik, memungkinkan berpartisipasi dalam kehidupan sosial budaya, politik dan memenuhi kebutuhan emosional. Secara khusus, pemahaman bacaan memiliki hubungan yang positif dengan prestasi yang dicapai siswa di sekolah (Durukan, 2011).

Sekolah tempat siswa belajar, sebagian besar menyajikan materi informasi dalam bentuk bacaan melalui buku paket, catatan guru atau melalui materi internet. Ketika siswa tidak mampu mengerti apa yang disajikan melalui bacaan, maka proses pembelajaran siswa akan terganggu. Hal ini merupakan salah satu faktor yang menjadikan pemahaman bacaan perlu diajarkan sejak dini kepada siswa Sekolah Dasar. Pembelajaran pemahaman bacaan sudah dimulai sejak anak berada di kelas IV di mana materi pelajaran semakin banyak dan kompleks (Rahim, 2008). Pembelajaran membaca di kelas IV tidak hanya sekedar proses membaca kata demi kata (recording dan decoding), namun tuntutan sekolah semakin sulit dimana siswa harus mencari makna (meaning) dari sebuah bacaan, dengan tingkat bacaan yang semakin sulit sesuai tingkatan kelas.

Pelajaran Bahasa Indonesia di tingkat Sekolah Dasar kelas V semakin kompleks. Kegiatan pembelajaran bahasa Indonesia di sekolah dasar diharapkan mampu mengembangkan dan mengarahkan siswa dengan segala potensi yang dimilikinya secara optimal (Haikal, 2010). Tuntutan kurikulum berdasarkan Silabus dalam pelajaran Bahasa Indonesia kelas $\mathrm{V}$ mengharuskan anak didik untuk bukan hanya sekedar membaca namun sudah harus menuliskan kembali ide pokok dan mengambil kesimpulan dari sebuah bacaan, oleh sebab itu dibutuhkan kemampuan pemahaman bacaan. Hasil survey awal menunjukkan bahwa hampir $60 \%$ siswa belum mampu memahami bacaan yang diberikan. Siswa belum mampu membuat kesimpulan bacaan atau mengambil nilai dan pesan bacaan.

Sedangkan hasil temuan berdasarkan wawancara dengan guru kelas menyatakan bahwa seringkali siswa masih kesulitan apabila harus memberikan kesimpulan, pendapat, atau meringkas dengan bahasa siswa sendiri. Kecenderungan siswa adalah ketika guru meminta siswa untuk memberikan pendapat, siswa hanya menyatakan setuju atau tidak setuju tanpa bisa menjelaskan alasan atau pendapat pribadi. Guru menjelaskan beberapa hal yang menyebabkan siswa belum bisa memenuhi kriteria yang diharapkan guru yaitu taraf kemampuan siswa yang berbeda, keadaan kelas yang ramai, bahan materi yang dibahas menarik atau tidak menarik minat siswa, dan metode pembelajaran di kelas yang 
masih menggunakan metode pembelajaran ceramah. Guru yang menggunakan metode pembelajaran ceramah menyebabkan siswa menjadi bosan, mengantuk, pasif dan hanya mencatat saja (Slameto, 2003).

Metode pembelajaran Cooperative Learning memiliki beragam metode, salah satunya adalah Cooperatif Integrated Reading Composition (CIRC). Metode pembelajaran CIRC dikembangkan oleh Stevans, Madden, Slavin, \& Farnish (Awalani, Sutarno, \& Ali, 2010). Dari segi bahasa dapat diartikan sebagai suatu model pembelajaran kooperatif yang mengintegrasikan suatu bacaan secara menyeluruh kemudian mengkomposisikannya menjadi bagian-bagian yang penting (Awalani, Sutarno, \& Ali, 2010). Tujuan utama dari metode pembelajaran CIRC adalah menggunakan tim-tim kooperatif untuk membantu para siswa mempelajari kemampuan memahami bacaan yang dapat diaplikasikan secara luas.

Metode pembelajaran CIRC memiliki kelebihan dan kekurangan. Kelebihan metode pembelajaran CIRC diantaranya dapat lebih memahami bacaan/ wacana/ kliping dan tidak bergantung pada teks tertentu, dapat meningkatkan kemampuan siswa dalam memberikan suatu solusi terhadap permasalahan yang diberikan guru, dapat digunakan untuk siswa yang memiliki tingkat kemampuan rendah, meningkatkan aktivitas selama pembelajaran berlangsung, serta meningkatkan rasa percaya diri siswa karena mereka bisa menemukan sendiri konsep dan materi yang dipelajari dan menyampaikan pendapat di dalam kelas. Sedangkan kelemahan dari metode pembelajaran CIRC menurut
Hannigan (Slavin, 2005) adalah membutuhkan waktu yang tidak sedikit, sulit mengatur kelas untuk diam sehingga suasana kelas cenderung ramai, guru harus mampu dan pandai mengatur waktu yang ada dan menguasai kondisi kelas agar pelaksanaan pembelajaran dapat berlangsung baik.

Metode pembelajaran CIRC terdiri atas tiga bagian penting, yaitu aktivitas dasar, instruksi langsung dalam membaca pemahaman, serta pengintegrasian bahasa dalam seni dan menulis (Slavin, 2005). Pemahaman bacaan merupakan suatu proses kognitif, berupa masuknya informasi baru ke dalam kognitif, bergabung dengan pengetahuan awal yang telah diketahui dan akhirnya mendapatkan informasi baru. Informasi baru diterima melalui persepsi visual, masuk ke dalam memori, untuk membangun suatu pengertian baru. Di dalam proses kognitif terdapat suatu bagian yakni memori yang merupakan pusat dari proses kognitif dan mempengaruhi hampir sebagian besar proses. Atkinson dan Shiffrin (Matlin, 1989) membagi model memori ke dalam 3 bagian yaitu: Sensory Register (sensory memory), Short Term Memory (STM) dan Long Term Memory (LTM).

Metode pembelajaran CIRC merupakan metode pembelajaran yang mengakomodasikan proses kognitif dalam membaca. Metode pembelajaran CIRC dilakukan secara bertahap, mengaplikasikan proses kognitif secara nyata untuk membantu siswa dalam memahami bacaan. Proses masuknya informasi baru secara luas dilakukan melalui sensory register. Sensory register memiliki kapasitas yang sangat 
besar, dapat menampung semua informasi dengan tepat dari indera, namun informasi tersebut tidak dapat bertahan lama (Matlin, 1989). Informasi dapat bertahan di sensory register selama kurang lebih 250 milidetik 4 detik (Solso, Maclin \& Maclin, 2008). Informasi yang masuk ke dalam sensory register akan diseleksi melalui proses attention (perhatian). Attention (perhatian), yaitu proses memfokuskan pada stimuli tertentu. Atkinson dan Shiffrin (Matlin, 1989) menyatakan bahwa informasi yang disajikan secara visual akan lebih mudah mendapatkan perhatian di sensory register. Setelah informasi diambil melalui proses attention, maka informasi akan dikodekan (coding), yaitu proses memodifikasi informasi dengan suatu proses mental (Solso dkk., 2008).

Siswa memiliki karakteristik bahwa perhatian yang dimiliki seringkali berpindah dengan cepat dari satu hal ke hal lain dengan mudah terarah pada objek dan kejadian yang tidak berhubungan dengan tugas yang sedang dikerjakan (Ormrod, 2008). Sementara itu, penyandian informasi di dalam sensory register dilakukan dalam bentuk visual (Matlin, 1989). Untuk memudahkan penyandian dan menarik attention siswa kepada aktivitas maupun tugas membaca, metode pembelajaran CIRC memfasilitasi dengan memberikan bahan bacaan kepada siswa. Memberikan bahan bacaan berarti informasi disajikan secara visual. Setelah siswa menerima bahan bacaan, guru mulai membacakan bahan bacaan untuk siswa, sementara siswa membaca dan menyimak. Aktivitas guru membacakan dan menyimak cerita juga bertujuan untuk mempertahankan dan segera memindahkan informasi menuju ke Short Term Memory (STM).

Short Term Memory adalah komponen memori tempat untuk memusatkan perhatian pada informasi untuk waktu yang singkat. STM terdiri dari sejumlah kecil dari informasi yang secara aktif digunakan. Informasi di STM dikodekan secara akustik melalui suara. STM memiliki kapasitas sekitar 2-7 item dengan jangka waktu sekitar 12 detik. Kapasitas untuk menyimpan informasi di STM bersifat sangat terbatas dan rentan terhadap memudarnya informasi secara cepat (Solso dkk, 2008). Atkinson dan Shiffrin menyatakan (Matlin, 1989) control processes, strategi yang digunakan untuk mempertahankan informasi yaitu dengan rehearsal (pengulangan). Rehearsal adalah pengualangan informasi yang bertujuan untuk mempertahankan informasi di STM.

Metode pembelajaran CIRC memfasilitasi siswa untuk menyimpan informasi melalui pengulangan (rehearsal) yakni dengan cara membaca nyaring (sandi auditorik). Proses rehearsal dilakukan berulang kali karena informasi tersebut mudah sekali hilang dan tidak bertahan lama. Informasi yang secara rutin diulang di dalam STM akan lebih mudah ditransfer menuju ke Long Term Memory (Matlin, 1989). Tugas-tugas yang diberikan dalam metode pembelajaran CIRC memang bertujuan untuk mengulang dan mempertahankan informasi. Tahap membaca nyaring dalam metode pembelajaran CIRC dilakukan dengan berpasangan, siswa diminta untuk membaca kembali bacaan sesuai intonasi, tanda baca, dan penyusunan kata di dalam bacaan. Sementara itu, 
teman yang mendengarkan bertugas untuk mengkoreksi tiap kesalahan yang dibuat, guru juga perlu untuk berkeliling dan mendengarkan saat siswa membaca nyaring. Ketika membaca nyaring, pengulangan dilakukan untuk mempertahankan informasi masuk melalui auditori, visual, dan motorik siswa yang diminta membaca sambil bersuara nyaring sehingga diri sendiri dan teman pasangan ikut mendengarkan. Melalui rehearsal, informasi dari bacaan diharapkan dapat bertahan di Short Term Memory. Penelitian terhadap membaca nyaring oleh Dahl dan Samuels (Slavin, 2005) mengindikasikan pengaruh positif terhadap kemampuan membaca pesan dan pemahaman.

Informasi yang telah diulang di Short Term Memory pada akhirnya masuk ke Long Term Memory (LTM). Karakteristik Long Term Memory adalah memiliki durasi yang tidak terbatas dan mampu menyimpan banyak informasi, semakin banyak informasi disimpan di Long term Memory, semakin mudah seseorang mempelajari hal-hal baru (Ormrod, 2008). Informasi di LTM dikodekan secara semantik melalui pemaknaan (meaning). Informasi di LTM juga tidak dapat hilang namun seringkali pemanggilan informasi di LTM tidak dapat diakses akibat adanya interferensi/ gangguan dari informasi-informasi baru (Matlin, 1989). Kegunaan Long Term Memory adalah mengawasi stimuli dalam sensori register, sehingga mengendalikan informasi (attention) yang memasuki penyimpanan jangka pendek dan menyediakan ruang penyimpanan bagi informasi dalam penyimpanan jangka pendek (Solso dkk, 2008).
Tugas selanjutnya dalam metode pembelajaran CIRC yaitu siswa diminta mengerjakan tugas secara kelompok (Mencari Harta Karun). Tugas "Mencari Harta Karun I", merupakan tugas kelompok yang bertujuan untuk membantu siswa mencapai pemahaman literal. Tugas "Mencari Harta Karun II", bertujuan untuk membantu siswa mencapai pemahaman interpretasi. Ketika siswa mengerjakan tugas kelompok, siswa mengerjakan tugas secara langsung dan bermakna melalui media diskusi kelompok. Tugas "Mencari Harta Karun I" merupakan tugas untuk mengulang kembali cerita secara keseluruhan dengan mengidentifikasi tokoh, tempat kejadian, kapan, sebab akibat dan proses. Sedangkan Tugas "Mencari Harta Karun II" merupakan tugas untuk membuat kesimpulan, generalisasi, sebab akibat, membuat perbandingan dan menemukan fakta baru. Di dalam tugas ini, siswa diajak secara aktif untuk menggunakan informasi dari Long Term Memory dan menggunakan informasi yang baru saja diperoleh melalui bahan bacaan. Dengan secara aktif menggunakan informasi baru dari bahan bacaan dan menggabungkan informasi lama untuk menjawab pertanyaan bacaan melalui diskusi kelompok, maka terjadi proses aktif di dalam Short Term Memory (working system). Dan ketika informasi tersebut secara aktif digunakan di STM maka informasi dan pengetahuan baru akan masuk ke Long Term Memory.

Akhir metode pembelajaran CIRC terdapat tahap tes/ kuis yang merupakan bagian akhir yaitu siswa dapat bekerja sendiri untuk mengetahui informasi baru yang diperoleh dari bacaan. Guru memberikan kembali pertanyaan bacaan untuk 
mengulang kembali pengetahuan yang telah diketahui siswa dari bahan bacaan. Tahap ini merekonstruksi kembali informasi yang diperoleh dari proses diskusi kelompok Pada akhirnya, siswa memperoleh pemahaman dan informasi baru.

Tujuan penelitian ini adalah untuk mengetahui pengaruh metode pembelajaran Cooperatif Integrated Reading Composition (CIRC) terhadap peningkatan kemampuan pemahaman bacaan bagi siswa kelas $\mathrm{V}$ Sekolah Dasar. Hipotesis penelitian ini adalah tidak ada perbedaan kemampuan pemahaman bacaan bagi siswa kelas $\mathrm{V}$ Sekolah Dasar dengan yang menggunakan metode pembelajaran Cooperative Integrated Reading and Composition (CIRC) dan yang tidak menggunakan metode pembelajaran Cooperative Integrated Reading and Composition (CIRC).

METODE PENELITIAN

\section{Subjek Penelitian}

Populasi pada penelitian ini adalah siswa kelas V SD Tinjomoyo 01 Semarang. Dalam tahap perkembangan kognitif Piaget, siswa berada dalam kategori operasional formal, siswa dapat memikirkan dan membayangkan konsep-konsep yang tidak berhubungan dengan realitas konkret, mampu mengenali kesimpulan logis sekalipun kesimpulan tersebut berbeda dari keseharian (Ormrod, 2008). Sementara itu, materi pelajaran siswa kelas $\mathrm{V}$ yang diberikan berbeda dan bertambah sulit, terutama bacaan yang diberikan akan semakin banyak dan membutuhkan kemampuan untuk memahami.

\section{Metode Pengumpulan Data}

Data dalam penelitian ini dikumpulkan melalui metode wawancara, observasi, metode dokumentasi dan metode test prestasi. Peneliti menggunakan rancangan penelitian eksperimen model "PretestPosttest Design", mengadaptasi dari Christensen (2004), digambarkan sebagai berikut:

\begin{tabular}{|c|c|c|c|c|}
\hline & $\begin{array}{l}\text { Pre } \\
\text { response } \\
\text { Measure }\end{array}$ & Treatment & $\begin{array}{c}\text { Post } \\
\text { response } \\
\text { Measure }\end{array}$ & Difference \\
\hline $\begin{array}{c}\text { Experimental } \\
\text { Group }\end{array}$ & Y & $X$ & Y & Pre-Y - Post-Y \\
\hline $\begin{array}{l}\text { Control } \\
\text { Group }\end{array}$ & $\mathbf{Y}$ & & Y & Pre-Y - Post-Y \\
\hline
\end{tabular}

Gambar 1. Rancangan Penelitian Model "Pretest-Posttest Design"

\section{Metode Analisis Data}

Metode analisis data yang digunakan adalah U Mann Whitney karena memiliki tujuan untuk mengetahui perbedaan hasil peningkatan kemampuan pemahaman bacaan pada kelompok eksperimen dan kelompok kontrol. Untuk membantu menghitung maka akan digunakan program komputer SPSS (Stastistical Packages for Social Sciences) versi 16. 
Tabel 1. Hasil Penghitungan Ranking Kelompok Kontrol dan Kelompok Eksperimen

\begin{tabular}{|ll|c|c|c|}
\hline & Kelompok & N & $\begin{array}{c}\text { Mean } \\
\text { Rank }\end{array}$ & $\begin{array}{c}\text { Sum of } \\
\text { Ranks }\end{array}$ \\
\hline Gainscore & Kontrol & 14 & 14,54 & 203,50 \\
& eksperimen & 15 & 15,43 & 231,50 \\
& Total & 29 & & \\
\hline
\end{tabular}

Hasil penghitungan diperoleh $\mathrm{U}^{\prime}=$ 111,5 dan nilai $U=98,5$. Dengan $\alpha=0,05$ maka diperoleh nilai $U$ tabel $=66$. Karena nilai $U$ hitung lebih besar dari nilai $\alpha(U \geq$ $U_{\alpha}$ ), maka dapat disimpulkan bahwa Ho diterima, artinya bahwa tidak ada perbedaan kemampuan pemahaman bacaan bagi siswa kelas V Sekolah Dasar yang menggunakan metode pembelajaran Cooperative Integrated Reading and Composition (CIRC) dan yang tidak menggunakan metode pembelajaran Cooperative Integrated Reading and Composition (CIRC).

Hasil observasi di kelas eksperimen, pada awalnya guru mengaktifkan informasi yang telah dimiliki siswa melalui proses pra baca, guru menyampaikan tema, tujuan pembelajaran secara menyeluruh kepada siswa. Tahap atensi dalam sensory register merupakan salah satu tahapan penting dalam penerimaan informasi awal. Apabila tahap ini tidak dapat dimaksimalkan, maka informasi akan cepat memudar dan hilang. Di kelompok eksperimen, usaha yang telah dilakukan Guru untuk menarik atensi siswa dengan menyampaikan tujuan, tema dan bacaan secara lisan saja ternyata tidak cukup efektif. Sensory register melakukan penyandian informasi secara visual, sedangkan guru memberikan tema, tujuan, dan menyampaikan bacaan secara lisan (audio) ternyata tidak cukup untuk menarik atensi dan melakukan penyandian visual bagi siswa. Oleh sebab itu, banyak siswa yang hanya sekedar ikut membaca namun tidak secara benar dapat menangkap dan mempertahankan informasi dari bacaan di dalam sensory register.

\section{PEMBAHASAN}

Masuk ke dalam diskusi siswa, proses rehearsal dilakukan untuk mempertahankan informasi masuk ke dalam Short Term Memory, diawali dari proses membaca nyaring secara berpasangan. Tahapan membaca nyaring menurut Harris dan Sipay (Rahim, 2008) merupakan suatu cara yang cepat dan valid untuk mengevaluasi kemajuan keterampilan membaca, khususnya berkaitan dengan pemenggalan kata dan frase. Saat membaca nyaring, siswa berpasangan saling bergantian membaca bahan bacaan. Namun ada juga siswa terlihat canggung serta masih banyak siswa yang tidak membaca dengan bersuara keras. Guru sebagai fasilitator siswa bertindak tanggap dengan menyuruh siswa untuk membaca dengan bersuara keras sehingga dapat didengar oleh pasangan. Membaca nyaring pada dasarnya merupakan aktivitas yang bertujuan untuk menangkap serta memahami informasi bacaan bagi pembaca dan pendengar. Ketika membaca nyaring, pembaca harus terampil dalam membaca lambang-lambang 
tertulis, mengelompokkan kata-kata dengan baik dan tepat sehingga jelas maknanya bagi pendengar (Tarigan, 2008). Namun yang terjadi, proses membaca berpasangan kurang efektif untuk mengulang dan mempertahankan informasi secara tepat di Short Term Memory (STM). Proses membaca nyaring yang dilakukan bersama-sama dengan anggota kelompok lain juga membuat suasana kelas ramai. Penjelasan ini menunjukkan bahwa aktivitas membaca nyaring kurang berfungsi secara maksimal untuk mempertahankan informasi dari bacaan karena siswa gagal mengulang informasi dan terganggu dengan keadaan lingkungan kelas yang ramai. Hannigan (Slavin, 2005), menjelaskan bahwa kelemahan dari metode pembelajaran CIRC adalah membutuhkan waktu yang tidak sedikit, sulit mengatur kelas untuk diam sehingga suasana kelas cenderung ramai. Keadaan kelas yang ramai merupakan penyebab terjadinya interferensi, yaitu gangguan dari informasi yang baru masuk ke dalam ingatan terhadap informasi yang telah disimpan, seolah-olah informasi lama digeser dan kemudian lebih sukar diingat (Winkel, 2004).

Siswa yang sudah menyelesaikan tugas membaca nyaring, kemudian mendapatkan tugas kelompok diskusi untuk bekerja menjawab pertanyaan jawaban. Kegiatan diskusi memang baik untuk merangsang debat dan mengeluarkan pendapat siswa. Aktivitas diskusi memfasilitasi pembelajaran secara aktif untuk mempertahankan dan mengolah informasi di Short Term Memory (STM). Siswa memiliki kesempatan untuk berdiskusi aktif, siswa memiliki pengetahuan awal untuk dikaitkan dengan informasi baru, dan siswa menyadari bahwa informasi yang dipelajari sebelumnya memiliki kaitan dengan informasi baru (Ormrod, 2008). Proses diskusi tidak berjalan dengan baik karena siswa saling bercanda dan adanya siswa pengekor "Free Rider". Siswa pengekor membuat pembelajaran melalui diskusi kelompok menjadi terganggu. Misalnya ketika siswa mengerjakan tugas kelompok "Mencari Harta Karun II" siswa cenderung tidak berdiskusi dan lebih menggantungkan diri pada siswa lain yang dianggap lebih pandai. Beberapa siswa yang menjadi siswa pengekor gagal untuk melakukan pembelajaran bermakna yang bertujuan untuk mempertahankan informasi di Long Term Memory (LTM). Siswa yang menjadi "Free Rider" akhirnya gagal untuk mengulang mempertahankan dan mengaktifkan informasi di Short Term Memory, sehingga informasi tersebut gagal untuk masuk ke dalam Long Term Memory. Schacter (Ormrod, 2008) menyatakan bahwa kegagalan untuk menyimpan atau lupa merupakan suatu keadaan dimana informasi tidak mencapai memori jangka panjang untuk disimpan.

Faktor lain yang menyebabkan metode pembelajaran CIRC kurang efektif untuk meningkatkan kemampuan pemahaman siswa adalah metode pembelajaran CIRC merupakan metode pembelajaran yang baru dan belum pernah digunakan sebelumnya. Tahapan yang dilalui dalam proses pembelajaran terdiri dari beberapa bagian sehingga baik guru dan siswa yang belum pernah mengalami terlihat canggung dan tidak biasa. Terutama pada hari pertama dan kedua pemberian metode 
pembelajaran CIRC. Penggunaan metode pembelajaran yang baru mengakibatkan guru dan siswa membutuhkan waktu untuk menyesuaikan dan membiasakan diri dengan metode pembelajaran CIRC. Hal inilah yang menyebabkan penggunaan metode pembelajaran CIRC tidak berfungsi maksimal untuk meningkatkan kemampuan pemahaman siswa. Sementara itu metode pembelajaran yang digunakan dalam kelompok kontrol merupakan metode yang biasa digunakan oleh Guru ketika mengajar di kelas. Metode ini menggabungkan metode ceramah, dan diskusi. Menggunakan metode pembelajaran non CIRC, berdasarkan hasil observasi, guru sebagai pemberi materi dan siswa bekerja secara individu, keadaan siswa lebih tenang dan terkendali. Guru lebih menguasai metode pembelajaran yang digunakan di kelompok kontrol. Kelompok kontrol terlihat lebih terkendali dan lebih tenang. Alokasi waktu yang diberikan juga cukup sehingga seluruh kegiatan dalam pembelajaran dapat dilakukan dengan baik.

\section{SIMPULAN DAN SARAN}

\section{Simpulan}

Kesimpulan dari penelitian yang telah dilakukan yaitu metode pembelajaran Cooperatif Integrated Reading Composition (CIRC) tidak dapat meningkatkan kemampuan pemahaman bacaan bagi siswa kelas $\mathrm{V}$ Sekolah Dasar.

\section{Saran}

Saran bagi penelitian selanjutnya adalah perlu mempertimbangkan aspek pemilihan waktu pelaksanaan penelitian yang lebih tepat. Hal ini bertujuan supaya ketika dilakukan pengukuran dan penelitian keadaan siswa tidak sedang mengalami kelelahan.

\section{DAFTAR PUSTAKA}

Abdurrahman, M. (1999). Pendidikan Bagi anak Berkesulitan Belajar. Jakarta: Rineka Cipta.

Awalani, I, Sutarno, H., \& Ali, E. N. (2010). Penerapan Model Pembelajaran Cooperative Integrated Reading And Composition (CIRC) Berbasis Komputer Untuk Meningkatkan Hasil Belajar Siswa Pada Pembelajaran TIK. Jurnal Pendidikan Teknologi Informasi dan Komunikasi (PTIK), 3 (1). Diunduh pada 2 Januari 2012 dari http://cs.upi.edu/uploads/paper_skri psi_dik.

Christensen, L. B. (2004). Experimental Methodology (9th Edition). Boston: Pearson Education, Inc.

Durukan, E. (2011). Effects of cooperative integrated reading and composition (CIRC) technique on reading-writing skills. Educational Research and Reviews, 6, 102-109. Diunduh tanggal 2 Januari 2012, dari http://www. academicjournals.org/ERR

Haikal. (2010). Apa Manfaat Belajar Bahasa Indonesia? Diunduh pada 12 Juli 2012, dari http://www.pelitakara wang.com/2010/04/apa-manfaatbelajar-bahasa-indonesia.html 
Matlin, M.W. (1989). Cognition (2nd Edition). New York: The Dryden Press.

Ormrod, J E. (2008). Psikologi Pendidikan: Membantu siswa tumbuh dan berkembangI. (Indianti, W., Septiana E., Saleh AY., Lestari, P.). Jakarta: Penerbit Erlangga.

Rahim, F. (2008). Pengajaran Membaca di Sekolah Dasar. Jakarta: Bumi Aksara.

Slameto. (2003). Belajar dan Faktor-faktor yang Mempengaruhinya. Jakarta: Penerbit Rineka Cipta.
Slavin, R.E. (1996). Educational Psychology, Fifth Edition. US : Allyn \& Bacon.

Solso, R.L., Maclin, O.H., \& Maclin, M. K. (2008). Psikologi Kognitif (Alih Bahasa: Rahardanto, M dan Batuadji, K.). Jakarta: Penerbit Erlangga.

Somadayo, S. (2011). Strategi dan teknik pembelajaran membaca. Yogyakarta: Graha Ilmu.

Tarigan, H G. (2008). Membaca Sebagai Suatu Keterampilan Berbahasa. Bandung: Angkasa.

Winkel, W.S. 2004. Psikologi Pengajaran. Yogyakarta: Penerbit Media Abadi. 